\title{
Ortaöğretim Biyoteknoloji Bilgi Testi (OBBT) ${ }^{1}$
}

\author{
The Secondary School Biotechnology Knowledge Test (SBKT) \\ Aysun SICAKER, ${ }^{2}$ Seray ÖZ AYDIN, ${ }^{3}$ Mesut SAÇKES ${ }^{4}$
}

• Geliş Tarihi: 22.07.2019 • Kabul Tarihi: 29.04.2020 • Çevrimiçi Yayın Tarihi: 29.04.2020

\begin{abstract}
$\ddot{O} z$
Biyoteknoloji bilimi, dünyanın geleceği açısından çok önemlidir. $\mathrm{Bu}$ nedenle toplumun her bireyinin günlük yaşamında kullanabilmesine yetecek ölçüde doğru biyoteknoloji bilgisine sahip olması gereklidir. Bu gereklilik doğrultusunda bu çalışmada, ortaöğretim öğrencilerinin Biyoteknoloji ve Gen Mühendisliği konusu ile ilgili bilgi düzeylerini belirlemek için bir ölçek geliştirmek amaçlanmıştır. Çalışmada öncelikle Biyoteknoloji Bilgi ve Kavramlar Anketi (BKBA) oluşturulmuştur. BKBA'nın uygulanması sonucu elde edilen veriler doğrultusunda dört aşama sonunda 30 sorudan oluşan Ortaöğretim Biyoteknoloji Bilgi Testi (OBBT) geliştirilmiştir. OBBT’nin örnekleme uygunluğu, ölçekten elde edilen puanların güvenirliği ve geçerliği Rasch analizi ile kontrol edilmiştir. Bunun sonucunda geliştirilen; ölçek tek boyutludur (Tüm maddelerin infit-outfit değerleri .05 ile 1.2 arasındadır), ölçeğin yapı geçerliliği uygundur, ölçekten elde edilen puanların güvenirliği .73' dür, ölçeği oluşturan maddelerin bilen ile bilmeyeni ayırt edebilecek güçte olduğu (madde ayırtedicilik indeksi 1.67' dir.) test edilmiştir, ölçekte yanlı madde yoktur. Ayrıca uzman görüşleri doğrultusunda ölçme aracının kullanışlı ve kapsam geçerliğinin uygun olduğuna karar verilmiştir.
\end{abstract}

Anahtar sözcükler: Ortaöğretim, ortaöğretim biyoteknoloji bilgi testi, biyoteknoloji, ölçek geliştirme, rasch analizi.

Atıf:

Sicaker, A., Öz Aydın, S. ve Saçkes, M. (2020). Ortaöğretim biyoteknoloji bilgi testi (OBBT). Pamukkale Üniversitesi Eğitim Fakültesi Dergisi, 50, 426-448. doi: 10.9779/pauefd.595078

\footnotetext{
${ }^{1}$ Bu makale 1. Yazarın yüksek lisans tez çalışmasının bir kısmından oluşmaktadır

2 Öğretmen, Manisa Soma Borsa İstanbul Fen Lisesi, ORCID ID: 0000-0001-7615-7440 asicaker@hotmail.com

3 Doçent Dr, Balıkesir Üniversitesi Necatibey Eğitim Fakültesi, ORCID ID:0000-0002-0635-0728 soz@balikesir.edu.tr

${ }^{4}$ Doçent Dr, Balıkesir Üniversitesi Necatibey Eğitim Fakültesi, ORCID ID:0000-0003-3673-1668 msackes@gmail.com
} 


\begin{abstract}
The science of biotechnology is essential for the future of societies. That's why every individual in society needs accurate biotechnology knowledge to associate it with their daily lives. Based on this requirement, the present research aimed to develop a scale to determine secondary school students' knowledge levels on biotechnology and genetic engineering topics. We started the present study with constituting "The Biotechnology Knowledge and Concepts Scale (BKCS)" according to The Turkish Secondary School Biology Curriculum. Next, we used the findings of BKCS in addition to the learning outcomes of the topic to form the 30-item true-false type "The Secondary School Biotechnology Knowledge Test (SBKT)" in four steps. We used Rash Measurement Model to test the convenience of the sample, the validity, and reliability of the scores obtained from SBKT (The Secondary School Biotechnology Knowledge Test). Data analysis with Rash Measurement model showed that SBKT is unidimensional (infit-outfit values are between .05 and 1.2). Also, SKBT produced valid and reliable scores (reliability index=.73), item discrimination index of the scale is 1.67 (which means the items sorts students who have mastered the material from students who have not), and there are no biased items in the scale. Besides, based on the field expert opinions, we decided that SKBT is convenient and has content validity.
\end{abstract}

Keywords: Secondary education, secondary school biotechnology knowledge test, scale development, rasch measurement model.

\title{
Cited
}

Sicaker, A., Öz-Aydın, S., \& Saçkes, M. (2020). The secondary school biotechnology knowledge test (SBKT). Pamukkale Üniversitesi Eğitim Fakültesi Dergisi, 50, 426-448. doi:10.9779/pauefd.595078 


\section{GíRiş}

Biyoteknoloji, canlıların doğrudan kullanılarak ya da teknolojik uygulamalarla yapılarının değiştirilmesi sonucu farklı veya özel bir durum için ürünler elde edilmesidir (Bruschi ve diğerleri, 2011). Biyoteknoloji bilimi tıptan tarıma, sağlıktan çevreye, sanayiden endüstriye birçok alanda kullanılmaktadır (Bilen ve Özel, 2012; Dundar ve Akbarova, 2011; Erbaş, 2008; Simonneaux, 2002). Modern biyoteknolojik yöntemler birçok alanda avantaj sağlayabileceği gibi birçok alanda da toplumlarda büyük bir endişeye ve huzursuzluğa sebep olmaktadır (Bayraç, Kalemtaş, Baloğlu, Kavas ve Önde, 2007; Bogner ve Torgersen, 2014; Çelik ve Balık, 2007; Çoban, 2004; Edmondston, Dawson ve Schibeci, 2010; Ho, 2001; Kefi, 2003; Kulaç, Ağırdil ve Yakın, 2006; Öktem, 2007; Simonneaux, 2002; Sürmeli, 2008). Uygulanan ve uygulanacak yöntemleri anlıyor olmak, bu konuda etik boyutları ve yasal düzenlemeleri bilmek modern biyoteknolojinin istenen doğrultuda yönlendirilmesini sağlayabilir (Mehta ve Gair, 2001) ve endişeleri sınırlayabilir. Ancak biyoteknoloji konusunda her birey kavramsal bilgilerden ziyade sentez, analiz düzeyinde, günlük hayat ile bağdaştırabilecek düzeyde bilgiye sahip olması ile yaşam kalitesini arttırabilecektir (Kirkpatrick, Orvis ve Pittendrigh, 2002; Wells, 1992).

Tüm bunlar geleceğin yetişkinlerinin biyoteknoloji konusunda temelden başlayarak, doğru, nesnel bilgilere sahip olarak bilinçli ve her türlü riskli duruma karşı hazır olarak yetiştirilmelerini (Doğru, 2010; Kolarova, 2011) kısacası biyoteknoloji okuryazarı bireyler olmalarını gerektirir (Chabalengula, Mumba ve Chitiyo, 2011; Harlen, 2001; Kwon, 2009). Biyoteknoloji okuryazarı bireyler, biyoteknoloji ile ilgili temel kavramları anlayabildiklerinde günlük yaşamlarında biyoteknoloji uygulamaları ile ilgili bilgi sahibi olarak karar verebilirler (Fonseca, Costa, Lencastre ve Tavares, 2012). Bunun için ise planlanmış biyoteknoloji eğitimi gerekir (Harms, 2002; Miller, 1994). Biyoteknoloji alanındaki hızlı gelişimin ve değişimin fark edildiği birçok ülkede bu konunun eğitimine gereken destek giderek arttırılmakta ve okullarda yaygınlaştırılmaya çalışılmaktadır (Miller, 1994; Pekşen, 2009) ya da bu konuda verilecek eğitimin önemi vurgulanmaktadır (Lamanauskas ve Makarskaitè-Petkevičienė, 2008). Çelik ve Erişen (2010)' in yaptığı "Ortaöğretim Düzeyinde Biyoloji Dersi Kapsamında Uygulanan Biyoteknoloji Programının Değerlendirilmesi" isimli çalışma sonucunda programın hedef, içerik, eğitim durumları, ölçme ve değerlendirme boyutlarında eksiklikleri olduğu belirtilmektedir.

Literatür incelendiğinde Biyoteknoloji eğitimi alanında kullanılan ölçme ve değerlendirme araçlarının genellikle, GDO bilgisi gibi bir boyutunu sorguladığı ya da programların kazanım ve hedeflerini tam olarak kapsamadığı, az sayıda bilgi sorusu içeren daha çok tutum, risk algısı, ilgi ölçmeye yönelik maddeler içeren ölçekler olduğu, örneklemin genellikle öğretmen adayları ve lisans eğitimi almış kamu çalışanları ile yapıldığı, az sayıda çalışmanın ortaöğretim öğrencileri ile yapıldığı görülmüştür (Bayoğlu ve Özgen, 2010; Bilen ve Özel, 2012; Darçın, 2007; Demir ve Pala, 2007; Demir ve Düzleyen, 2012; Ergin, Gürsoy, Öcek ve Çiçeklioğlu, 2008; Gürkan, 2013; Gürkan ve Kahraman, 2018; Kaya, 2015; Keskin, 2003; Keskin ve diğerleri, 2010; Koçak, Türker, Kılıç ve Hasde, 2010; Öcal, 2012; Öz Aydın, Sıcaker, Taşkın ve Şahin, 2016; Özdemir, Güneş ve Demir, 2010; Özel, Erdoğan, Uşak ve Prokop, 2009; Özgen, Emiroğlu, Yıldız, Taş ve Purutçuoğlu, 2007; Sıcaker, Çetin ve Öz Aydın, 2013; Sıcaker 
ve Öz Aydın, 2015; Sürmeli, 2008; Sürmeli ve Şahin, 2009; Tanır, 2005; Yılmaz ve Öğretmen, 2014; Yüce ve Yalçın, 2012).

Eğitimde ölçmeye konu olan özelliklerin çoğu (zeka, başarı, yetenek, kişilik, ilgi, tutum gibi) dolaylı olarak ölçülebilen özelliklerdir (Erkuş 2012; Tekin, 1991). Eğitimdeki ölçmelerin çoğunun dolaylı ölçme olması, ölçme sonuçlarına daha çok hata karışmasına sebep olur (Tekin, 1991). Dolaylı ölçmelerde hatayı en aza indirmek, ölçülebilecek davranışı en net şekilde ölçebilmek ulaşılmak istenen başlıca hedeflerden biridir. Ölçme araçlarından elde edilen sonuçlar bireylerin incelenen özellikleri ile ilgili düzeyleri hakkında karara (geçti/kaldı, başarılı/başarısız, bilgili/bilgisiz gibi) varmada kullanılır. Varılan yargılarının doğruluğu ise ölçmede kullanılan ölçme araçlarının ve yöntemlerinin niteliğine bağlıdır (Anıl, 2002).

Bir ölçme aracının ve araçtan elde edilen puanların sahip olması gereken güvenirlik, geçerlik, objektiflik, ayırt edicilik ve kullanışlılık gibi özellikler bulunmaktadır (Büyüköztürk, Kılıç Çakmak, Akgün, Karadeniz ve Demirel, 2010; Tekin, 1991). Oldukça zor ve uzun bir süreç olan ölçek geliştirmede takip edilmesi önerilen aşamaların sonuncusu ölçek ve madde analizidir. $\mathrm{Bu}$ aşamada testten elde edilen puanların güvenirliği, geçerliği, soruların uygulanan grup açısından zorluk derecesi, soruların ayırt edicilik indeksleri hesaplanır. Bu hesaplamalar için ise çeşitli analiz yöntemleri kullanılır (Erkuş, 2012).

$\mathrm{Bu}$ analiz yöntemleri Klasik Test Teorisi (KTT ya da Geleneksel Test Teorisi) veya Örtük Özellikler Teorisi (ÖÖT ya da Madde Tepki Kuramı) temellidirler (Gelbal, 1994a, 1994b; Öztuna, 2008). Bu çalışmada, Klasik Test Teorisine göre daha avantajlı olduğu düşünülen Madde Tepki Kuramının (Gelbal, 1994a, 1994b; Sünbül, 2011; Yu, 2013) tek boyutlu ikili modeli olan Rasch ölçüm modeli kullanılmıştır. Ölçme aracı geliştirme çalışmalarında kullanılan Rasch modeli Danimarka'lı matematikçi, istatistikçi ve psikometrist olan Georg Rasch tarafından geliştirilmiştir (Hambleton ve Swaminathan, 1985). Rasch analizi ile bireyler yeteneklerine, ölçek maddeleri ise güçlüklerine göre sıralanır ve bireylerin yeteneklerine uygun görevleri ne kadar yapabileceği olasıllı̆ı kestirilmeye çalışılır (Koparan ve Güven, 2013; Wright ve Stone, 1979). Yani kişinin bir soruya doğru cevap verebilmesi için ilgili sorunun zorluk derecesinin bireyin yeteneğinden yüksek olmaması gerekir (Gelbal, 1994a, 1994b).

Rasch ölçüm modelinin kişiyi sadece görünen puana göre değerlendirmemesi, maddeleri güçlüklerine-bireyleri yeteneklerine göre değerlendirmesi, her bireyi örneklemden bağımsız değerlendirmesi, yanlı maddeleri belirleyebilmesi, bireyleri farklı kategorilere göre ayr1 ayrı değerlendirebilmesi gibi özellikleri (Boone ve Scantlebury, 2005; Wright ve Mok, 2004) ölçek geliştirme çalışmalarında büyük bir avantaj sağlar. Tüm bu avantajlar düşünüldüğünde Rasch ikili model Doğru/Yanlış, Evet/Hayır gibi iki kategorili ölçekler için rahatlıkla kullanılabilir (Boone ve Scantlebury, 2005).

Ülkemizde madde tepki kuramı ve Rasch modeli ile ilgili çalışmalara çok fazla rastlanılmamıştır. Yapılan çalışmalardan bazılarında (Anı1, 2002, Anı1, 2008; Atılgan, 2004; Berberoğlu, 1988; Çepni, 2011; Çıkrıkçı Demirtaş11, 1995; Gelbal, 1994a, 1994b; Gök, 2012; Güler, 2008; Gültekin, 2011; Kelecioğlu, 1994; Kilmen, 2010; Köse, 2012; Özkan Özer, 2012; Özkaya Seçil, 2009; Öztuna, 2008; Sünbül; 2011) klasik test teorisi ile madde tepki kuramının karşılaştırılması yapılmış, bazılarında ise madde tepki kuramının tanıtılmasına yer verilmiştir. Sonuç olarak ise madde tepki kuramı modellerinin ölçme konusunda genelde daha başarılı olduğu sonucuna varılmıştır. Karşılaştırma ve araştırma çalışmalarının dışında, ayrıca rasch 
modelinin kullanıldığ deneysel çalışmalar ve ölçek geliştirme çalışmaları da (Baştürk, 2010; Elhan, 2002; Elhan ve Atakurt, 2005; Kaptan, 1994; Kaskat1, 2011; Koparan ve Güven, 2013; Küçükdeveci, 2011; Semerci, 2011a, 2011b) bulunmaktadır. Ancak bu çalışmalar genellikle tıp alanında ve eğitim bilimlerinde yapılmış çalışmalardır. Genel anlamda hepsi Rasch modellerinin kullanılmasının ölçme ve değerlendirmede daha iyi sonuçlara ulaştırdığını ifade etmişlerdir.

Alan yazında MEB ortaöğretim "Biyoteknoloji ve Gen Mühendisliği konusu" nun içeriği ve kazanımları çerçevesinde ortaöğretim öğrencileri için bir ölçek çalışmasına rastlanılmamıştır. Rash modeli ile geliştirilen bu ölçeğin farklı boyutlarda değerlendirme sağlayacağı ve eğitim alanında ortaöğretim öğrencilerinin biyoteknoloji ve gen mühendisliği konusu ile ilgili bilgi düzeylerini, yeterliklerini, yeteneklerini belirleme anlamında bir eksikliği dolduracağı ve biyoteknoloji eğitimine büyük bir katk1 sağlayacağı düşünülmektedir. Bu nedenle ortaöğretim öğrencilerinin Biyoteknoloji ve Genetik Mühendisliği konusu ile ilgili bilgi düzeylerini belirlemek için kullanılabilecek bir ölçek geliştirmek amaçlanmıştır.

\section{Yöntem}

$\mathrm{Bu}$ çalışmada geleneksel ölçme araçlarından biri olan doğru/yanlış testi geliştirilmiştir. Doğru yanlış testleri bir konu ile ilgili genel ifadeleri, olayların nedensel ilişkilerini, olayların sonuçlarına yönelik tahminleri, bir sürecin basamaklarını test etmek için kullanılabilir (Bahar, Nartgün, Durmuş ve Bıçak, 2010). Ancak doğru yanlış testleri şans başarısının yani şansla doğru yanıtlama ihtimalinin yüksek olduğu testlerdir (Tekin, 1991). Şans başarısını azaltmanın yollarından biri cevaplayıcılardan soruları cevaplarken doğruysa neden, yanlışsa neden şeklinde açıklama yapmalarının istenmesidir (Bahar ve diğerleri, 2010). Bir diğer yolu da öğrencilerin sinava iyi motive edilmeleridir.

\section{Örneklem}

$\mathrm{Bu}$ araştırmanın örneklemini Marmara bölgesinde bir ilde bulunan ortaöğretim 11. ve 12. sınıf öğrencileri oluşturmaktadır.

Örneklemin ortaöğretim öğrencilerinden oluşturulmasının sebebi zorunlu eğitim gereği her öğrenci ortaöğretim seviyesini tamamlamakta, ancak her öğrenci lisans eğitimine devam etmemektedir, dolayısıyla bu dönemde alınacak biyoteknoloji eğitimi lisans eğitimine devam edecek öğrenciler için temel, devam etmeyen öğrenciler için hayat boyu kullanacakları bilgiler haline gelecektir.

\section{Pilot çalışmada örneklem}

Çalışmada esas uygulama gerçekleştirilmeden önce veri toplama araçlarının geliştirilmesi amacıyla 2 ayrı pilot uygulama yapılmıştır. İlk pilot uygulama bir üniversitenin Fen Bilgisi Öğretmenliği 3. sınıf öğrencileri (78 öğrenci) ile ikinci pilot uygulama ise Balıkesir merkezde yer alan bir kurstaki sayısal bölüm 11. ve 12. sınıf öğrencileri (150 öğrenci) ile yapılmıştır.

\section{Esas çalışmada örneklem}

Balıkesir il merkezinde bulunan bir kurstaki ortaöğretim 11. sınıf ve 12. sınıf sayısal bölüm öğrencilerinden rastgele seçilen 221 öğrenci bu çalışmanın örneklemini oluşturmaktadır. Örneklemin kurstan seçilme sebebi birçok farklı okul öğrencisine ulaşma kolaylığı sağlamasıdır. Tablo 1' de örneklemin sınıflara göre dağılımı görülmektedir. 
Tablo 1. Esas Çalışmayı Oluşturan Örneklemin Sınıflara Göre Dağılımı

\begin{tabular}{lc}
\hline Sinıf & Öğrenci Sayıs \\
\hline 11. Sinıf & 148 \\
12. Sinıf & 73 \\
Toplam & 221 \\
\hline
\end{tabular}

\section{Veri Toplama Aracının Geliştirilmesi}

Bu çalışma Sıcaker (2019) tarafından hazırlanan yüksek lisans tezi olan "Biyoteknoloji Ve Gen Mühendisliği Konusunda Ortaöğretim Öğrencilerine Yönelik Rasch Analizi İle Ölçek Geliştirme"nin bir bölümü dikkate alınarak hazırlanmıştır. Tez çalışmasında Biyoteknoloji Bilgi Testi geliştirilmeden önce Biyoteknoloji Kavram ve Bilgi Anketi (BKBA) geliştirilmiş ve uygulanmıştır (Sıcaker ve Öz Aydın, 2015). BKBA, ortaöğretim 11. sınıflarda kullanılan MEB biyoloji ders kitabının "Biyoteknoloji ve Gen Mühendisliği" konusu ve kazanımları doğrultusunda öğrencilerden, Transgenik Organizma, DNA Analizi, GDO (Genetiği Değiştirilmiş Organizma), Biyogüvenlik gibi 45 kavramla ilgili düşünceleri alınmıştır. BKBA, öğrencilerin düşüncelerini "çok zor"...." çok kolay" şeklinde ifade etmelerini sağlayan beşli likert tipinde bir ankettir. Bu anketten elde edilen bulgular geliştirilecek OBBT için madde havuzu oluşturulmasına katlı sağlamıştır. Örneğin, öğrencilerin çoğunluğu tarafından "çok kolay" olarak belirtilen kavramı daha ayrıntısı ile sorgulayan sorular havuza eklenmiştir.

\section{Ortaöğretim Biyoteknoloji Bilgi Testi (OBBT)' nin Geliştirilmesi}

Biyoteknoloji Kavram ve Bilgi Anketinden elde edilen bulgular ve konuya ait Milli Eğitim Bakanlığı (MEB, 2013) kazanımları doğrultusunda biyoteknoloji konusuna yönelik bilgi düzeyini ölçmek ve öğrencilerin bu konuyla ilgili eksikliklerini belirlemek amacıyla OBBT hazırlanmıştır. OBBT bir başarı testidir. OBBT geleneksel ölçme ve değerlendirme tekniklerinden biri olan doğru-yanlış sorularından oluşmaktadır. OBBT 4 aşamada geliştirilmiştir.

\section{Aşama OBBT taslağının oluşturulması}

BKBA'den elde edilen bulgular doğrultusunda 20 açık uçlu soru hazırlanmış ve bu sorular 10 . sınıf sayısal (30 öğrenci), 12. sınıf sayısal (20 öğrenci) ve eşit ağırlık (20 öğrenci) öğrencilerine uygulanmıştır. Kavramlar anketinden elde edilen bulgular, öğrencilerin 20 açık uçlu soruya verdiği cevaplar doğrultusunda ve konuya ait kazanımlar dikkate alınarak 62 soruluk (61 doğruyanlış ve 1 boşluk doldurma sorusu) OBBT' nin ilk hali elde edilmiştir.

$\mathrm{Bu}$ aşamada 10. sınıf sayısal öğrencileri ve eşit ağırlık 12. sınıf öğrencileri konuyu hiç öğrenmemişlerdir. Konuyu hiç görmemiş öğrencilere bu çalışmanın yapılma sebebi kavramların, konuyla ilgili çevreden öğrenilen bilgilerle yapılabilirliğini görmek ve soruları zenginleştirebilmektir. Sayısal 12. sınıf öğrencileri ise 11. sınıfta konuyu öğrenmişlerdir. Bu konuyu işlemiş olan öğrencilerin sahip oldukları bilgilerin durumu OBBT 'nin hazırlanmasına katkı sağlamıştır.

\section{Așama 62 soruluk OBBT' nin düzenlenmesi}

Birinci aşama sonunda oluşturulan 62 soruluk ( 61 doğru-yanlış ve 1 boşluk doldurma sorusu) OBBT Fen bilgisi öğretmenliği 3. sınıf öğrencilerine (87 kişiye) uygulanmış ve ayrıca 
öğrencilerin sorularla ilgili anlaşılırlık, zorluk kolaylık açısından görüşlerini cevap kağıdının arkasına yazmaları istenmiştir.

Öğrencilerin sorulara verdikleri cevaplar incelenerek her soruya verilen doğru ve yanlış cevap oranları belirlenmiştir. Bu oranlar ve öğrencilerin soruların anlaşılırlığı, zorluğu, kolaylığ ile ilgili görüşleri doğrultusunda, işlemeyen sorular ve herkesin doğru ya da yanlış olarak cevap verdiği sorular belirlenerek ölçekten çıkarılmış, bazı sorular ise tekrar düzenlenmiştir. İlgili sorular çıkarıldıktan sonra uzman görüşü alınmıştır.

Uzmanlar (iki Türk dili uzmanı, bir ölçme ve değerlendirme uzmanı, üç biyoloji öğretmeni ve biyoteknoloji konusunda çalışmalar yapan iki alan uzmanı) tarafından soruların anlaşılırlığ 1 ve doğruluğu incelenmiş ve uygun bulunmayan sorular ölçekten çıkarılmış, çift cevap gerektiren sorular uzman görüşü doğrultusunda tekrar düzenlenmiştir. Bu düzenlemeler sonucunda 49 soruluk ( 45 doğru-yanlış ve 4 boşluk doldurma ) OBBT hazırlanmıştır (EK D).

\section{Aşama OBBT'nin son halini alması}

45 doğru-yanlış ve 4 boşluk doldurma sorusundan oluşan 49 soruluk OBBT 12. sınıf sayısal öğrencilerine (73 öğrenciye) uygulanmıştır. Cevaplama işlemini tamamlayan öğrencilerin cevaplama süreleri cevap kağıtlarına yazılmış ve bu sürelerden yararlanılarak testin cevaplanmasında ortalama ne kadar süre gerektiği belirlenmiştir. Öğrencilerden uygulama sırasında cevap kağıdının arkasına soruların anlaşılırlığı, zorluğu kolaylığı ile ilgili görüşlerini yazmaları istenmiştir. Uygulama sonunda örneklemden elde edilen puanların güvenirlik katsayısı (K-R) 0.774 bulunmuştur. Bu aşamanın sonunda elde edilen bulgular ve öğrencilerin cevap kağıtlarına yazdıkları görüşler doğrultusunda OBBT tekrar düzenlenmiştir. Ölçeğin kapsam ve görünüş geçerliliği için uzman (iki Türk dili uzmanı, bir ölçme ve değerlendirme uzmanı, iki eğitim uzmanı ve beş biyoloji eğitimi uzmanı) görüşü alınarak ölçek maddelerinde düzenlemeler yapılmıştır. Düzenlemeler sonucunda 2., 4., 7., 26., 33., 44. sorular ve boşluk doldurma soruları ölçekten çıkarılmıştır. Oluşturulan 39 soruluk OBBT çalışmanın 221 öğrenciden oluşan esas örneklemine uygulanmıştır.

4. aşamada 39 soruluk OBBT Rasch Modeli kullanılarak test edilmiş ve OBBT' nin 30 soruluk son haline ulaşılmıştır. Bu aşama sonuçları bulgular kısmında verilmiştir. Ölçeğe ait örnek sorular ekte verilmiştir.

\section{Verilerin Analizi}

BBT'den elde edilen verilerin analizinde ise Rasch Ölçüm Modellerinden "İkili (Dikotom) Model" kullanılmıştır. Bu modelin seçilme sebebi BBT'nin cevap formatına uygunluğudur. İkili model, soru maddelerinin "Katılıyorum/Katılmıyorum, Evet/Hayır, Doğru/Yanlış gibi iki kategoriden oluştuğu durumlarda kullanılabilir. Doğru cevap 1 puan olarak değerlendirilirken yanlış cevap 0 puan ile değerlendirilir (Elhan ve Atakurt, 2005; Wright \& Mok, 2004). Verilerin Rasch modeli ile analizinde WINSTEPS sürüm 3.65.0 kullanılmıştır.

Rasch ikili modelin uygulanabilmesi için belirli sayıltıların doğrulanması gerekir. Bu sayıltılar tek boyutluluk ve yerel bağımsızlıktır (Wuang, Lin and Su, 2009). Tek boyutluluk; ölçekteki her bir maddenin tek bir şeyi ölçüyor olmasını ifade eder. Bunun için test maddelerinin uygunluğuna, yani test maddelerinin INFIT ve OUTFIT değerlerinin belirlenen aralıkta olması kontrol edilir. Literatür incelendiğginde farklı aralıkların alındığı görülmüştür. 
Örneğin; Wright ve Linacre (1994)' nin yaptı̆̆g çalışmada 0.5 ile 1.5 aralığı, Chang ve Chan (1995)' in yaptığı çalışmada 0.6 ile 1.5 arası uygun değer aralığı kabul edilmiştir. Maddelerin yerel bağımsızlı̆̆ı; her maddenin puanının diğerinden bağımsız olmasıdır. Yani bir sorunun diğerinin puanlanmasında etkili olmamasıdır. Bu sayıltılar analiz sırasında kontrol edilir.

\section{Bulgular}

Ortaöğretim Biyoteknoloji Bilgi Testi (OBBT)' nin geliştirilmesinin en son aşamasında Rasch analiz yöntemi kullanılmıştır. Rasch modelinin veri setine uygunluğu için gerekli sayılttılar denetlenmiş ve veri seti ile Rasch modelin uyumlu olduğuna karar verilmiştir. Rash analizinin uygulanabilmesi için gerekli sayıltılar sorgulanmış ve bulguları aşağıda verilmiştir.

\section{FIT (Uyum) değerlerinin kontrol edilmesi}

Analiz sonucunda maddelerin INFIT (uygunluk içi) ve OUTFIT (uygunluk dışı) değerleri kontrol edilmiştir. Bu çalışmada 0.5 ile 1.2 arasındaki fit (INFIT, OUTFIT) değer aralığının uygun olduğu kabul edilmiştir. Bu değer aralığı dikkate alınarak "madde istatistik tablosu" incelenmiş ve FIT değeri belirlenen aralığın dışında (1.2 ve üzerinde) olan 9 madde ölçekten çıkarılmıştır. Ölçekten bu $(1,15,18,28,30,31,36,37,41$ numaralı) maddelerin çıkarılması sonucu OBBT'de toplam 30 madde kalmıştır. Kalan 30 maddenin FIT değerleri tablo 2'de verilmiştir.

\section{Tek boyutluluk}

Test maddelerinin INFIT ve OUTFIT değerlerinin belirlenen aralıkta olması test maddelerinin hepsinin aynı şeyi ölçtügünü yani testin tek boyutluluğunu gösterir. Bunun yanı sıra hatalar, temel bileşenler analizine tabii tutulduğunda ilk kontrastın özdeğerinin 2.3 olduğunu ve bu değerinde ölçekte ikinci bir boyut olabileceğinin işareti olan özdeğer 3 değerinden az olduğu gözlenmiştir. Birinci kontrastın özdeğerinin ve açıkladığı varyansın (özdeğer=2.3, varyans=6.0) madde güçlüğü (özdeğer=4.4, varyans $=11.5$ ) ve yeteneğin (özdeğer $=3.9$, varyans $=10.2$ ) özdeğeri ve açıkladığı varyanstan küçük olduğu görülmüştür. Bu kanıtlar ölçeğin tek boyutlu olduğuna işaret etmektedir. Temel bileşenler analizi tetrakorik korelasyon matrisi kullanılarak Winsteps sürüm 3.65 ile gerçekleştirilmiştir (Linacre,2006).

\section{Maddelerin yerel bağımsızlığı}

Testteki her maddenin birbirinden bağımsız olarak değerlendirilmesi, bir maddenin cevabının diğer maddeyi olumlu ya da olumsuz etkilememesi durumudur.

Tabloda 2' de görüldüğü gibi soru maddelerinin INFIT ve OUTFIT (MNSQ) değerleri 0.5 ile 1.2 arasındadır. $\mathrm{Bu}$ da bu ölçeğin yapı geçerliğinin uygun olduğunu ve verilerin Rasch modeli ile uyumlu olduğunu gösterir. Çünkü Rasch model ölçekleri tek boyutlu maddeleri, yerel bağımsız kabul eder. 
Tablo 2. Madde İstatistik Tablosu

\begin{tabular}{|c|c|c|c|c|}
\hline \multirow{2}{*}{ Madde No } & \multicolumn{2}{|c|}{ INFIT (Uygunluk İçi) } & \multicolumn{2}{|c|}{ OUTFIT (Uygunluk Dişı) } \\
\hline & MNSQ & ZSTD & MNSQ & ZSTD \\
\hline S42 & 1.03 & .5 & 1.19 & 1.7 \\
\hline S24 & 1.16 & 2.6 & 1.17 & 1.6 \\
\hline S14 & 1.13 & 2.9 & 1.17 & 2.1 \\
\hline $\mathrm{S} 25$ & 1.11 & 2.1 & 1.12 & 1.4 \\
\hline S13 & 1.07 & 1.5 & 1.10 & 1.3 \\
\hline S45 & 1.06 & 1.2 & 1.09 & 1.2 \\
\hline S22 & 1.06 & 1.2 & 1.07 & .9 \\
\hline S3 & 1.00 & .1 & 1.07 & .5 \\
\hline S8 & 1.02 & .4 & 1.07 & .8 \\
\hline S10 & 1.02 & .3 & 1.05 & 6 \\
\hline S5 & 1.05 & 1.1 & 1.01 & .2 \\
\hline S27 & 1.00 & -.1 & 1.04 & .5 \\
\hline S35 & .96 & -.2 & 1.04 & .2 \\
\hline S29 & 1.01 & .1 & 1.03 & .3 \\
\hline S34 & 1.00 & .1 & 1.01 & .2 \\
\hline S20 & .96 & -.5 & 1.00 & .1 \\
\hline $\mathrm{S} 12$ & 1.00 & .0 & .95 & -.5 \\
\hline S43 & .99 & .0 & .91 & -.3 \\
\hline S6 & .99 & -.1 & .96 & -.4 \\
\hline S38 & .98 & -.1 & .84 & -.6 \\
\hline S40 & .98 & -.2 & .91 & -.5 \\
\hline S32 & .98 & -.4 & .93 & -.8 \\
\hline S23 & .97 & -.4 & .95 & -.4 \\
\hline S19 & .95 & -1.0 & .92 & -.9 \\
\hline $\mathrm{S} 21$ & .94 & -1.3 & .91 & -1.2 \\
\hline S9 & .93 & -.9 & .88 & -1.0 \\
\hline S16 & .90 & -1.8 & .87 & -1.6 \\
\hline S11 & .89 & -1.4 & .81 & -1.5 \\
\hline S17 & .89 & -1.3 & .81 & -1.3 \\
\hline S39 & .89 & -2.4 & .87 & -1.6 \\
\hline
\end{tabular}

\section{Güvenirlik}

Rasch ölçüm modeline göre ölçekten elde edilen puanların güvenirliği (person reliability) .74'tür. Person reliability rasch analizinin kendine ait güvenirlik hesabıdır (Tablo 3). Bu değer (.74) bir başarı testi için yeterlidir (Muijs, 2011). Analizde ayrıca hesaplanan Cronbach Alpha (KR-20) Person Raw Score Reliability, yani KR-20 değeri .73’tür (Tablo 3).

Tablo 3. Güvenirlik

\begin{tabular}{|c|c|c|c|c|c|c|c|c|}
\hline \multicolumn{9}{|c|}{ SUMMARY OF 221 MEASURED PERSONS } \\
\hline & RAW & \multirow[b]{2}{*}{ COUNT } & \multirow[b]{2}{*}{ MEASURE } & \multirow{2}{*}{$\begin{array}{l}\text { MODEL } \\
\text { ERROR }\end{array}$} & \multicolumn{2}{|c|}{ INFIT } & \multicolumn{2}{|c|}{ OUTFIT } \\
\hline & SCORE & & & & MNSQ & ZSTD & MNSQ & ZSTD \\
\hline Ortalama & 17.9 & 30.0 & .52 & .43 & 1.00 & .0 & .99 & .0 \\
\hline S.S & 4.6 & .0 & .88 & .08 & .15 & 1.0 & .26 & 1.0 \\
\hline Maks. & 29.0 & 30.0 & 3.69 & 1.03 & 1.41 & 2.6 & 2.74 & 2.9 \\
\hline Min. & 1.0 & 30.0 & -3.69 & .39 & .68 & -2.6 & .25 & -2.4 \\
\hline \multirow{4}{*}{\multicolumn{3}{|c|}{$\begin{array}{ccc}\text { REAL RMSE } & .45 & \text { ADJ.SD } \\
\text { MODEL RMSE } & .44 & \text { ADJ.SD } \\
\text { S.E. OF PERSON MEAN }=.06 \\
\text { PERSON RAW SCORE-TO-ME }\end{array}$}} & \multicolumn{6}{|c|}{.76 SEPARATION 1.67 PERSON RELIABILITY .74 } \\
\hline & & & \multicolumn{2}{|c|}{77 SEPARATION 1.74} & \multicolumn{4}{|c|}{ PERSON RELIABILITY .75} \\
\hline & & & & & & & & \\
\hline & & & \multicolumn{6}{|c|}{ PERSON RAW SCORE-TO-MEASURE CORRELATION = .98 } \\
\hline
\end{tabular}




\section{Ayırma İndeksi (Separation)}

Rasch analizi sonucu ayırma indeksinin (separation) 5.24 olduğu bulunmuştur. Ayırma indeksi, değişkenlik kaynağındaki objelerin birbirinden ne kadar ayrıldığını gösteren bir ölçüdür. Bu değer maddelerin birbirinden iyi ayrıldığının göstergesidir. Bireyler ve maddeler için bu ölçünün büyük, puanlayıcılar için ise sıfıra yakın bir değer çıkması beklenir. Yüksek değere sahip bir ayırma indeksi, puanlayıcıların bir birlerinden ne kadar farklı puanlama yaptıklarının bir göstergesidir.

\section{Madde Yanlıı̆̆ğı (Ön Yargılı Madde) Analizi}

Rasch analizinin bir uygulaması olan DIF (Differential item functioning) analizi sonucunda ölçekteki maddelerin cinsiyete, sınıfa bağlı avantaj oluşturmadığı yani yanlı maddelerin olmadığı bulunmuştur. Tablo 4 'te görüldüğü üzere maddelere ilişkin logit değerleri 0.64 'den küçüktür (Boone, Staver ve Yale, 2013).

Tablo 4. Cinsiyete Göre Madde Yanlılığı Analizi Sonuçları

\begin{tabular}{lrrrrr}
\hline Madde No & $\begin{array}{r}\text { Erkek } \\
\text { DIF (Logit) }\end{array}$ & $\begin{array}{r}\text { Kadin } \\
\text { DIF (Logit) }\end{array}$ & Madde No & $\begin{array}{r}\text { Erkek } \\
\text { DIF (Logit) }\end{array}$ & $\begin{array}{r}\text { Kadin } \\
\text { DIF (Logit) }\end{array}$ \\
\hline S1 & -0.43 & 0.4 & S22 & 0 & 0 \\
S3 & -0.09 & 0.08 & S25 & 0.18 & -0.15 \\
S5 & -0.16 & 0.15 & S28 & 0.41 & -0.29 \\
S6 & -0.38 & 0.36 & S29 & -0.4 & 0.32 \\
S8 & 0 & 0 & S30 & 0.8 & -0.44 \\
S9 & -0.19 & 0.17 & S32 & 0.19 & -0.18 \\
S11 & -0.11 & 0.1 & S34 & 0.25 & -0.21 \\
S12 & 0 & 0 & S35 & 0 & 0 \\
S13 & 0.08 & -0.07 & S36 & -0.07 & 0.06 \\
S14 & 0 & 0 & S39 & 0 & 0 \\
S16 & 0.49 & -0.39 & S40 & -0.35 & 0.28 \\
S17 & 0.1 & -0.11 & S41 & -0.37 & 0.33 \\
S19 & 0.13 & -0.11 & S43 & 0.34 & -0.42 \\
S20 & -0.03 & 0.02 & S45 & 0.09 & -0.08 \\
S21 & 0.06 & -0.05 & S22 & 0 & 0 \\
\hline
\end{tabular}

\section{Madde Haritası}

Rasch analizi sonucu öğrenci yetenekleri ile madde güçlüklerini karş1laştırarak öğrencilerin yeteneklerine uygun olarak çözebilecekleri maddeleri gösteren "madde haritası" elde edilir. Madde haritasının incelenmesi sonucu, en zor soru, en kolay soru, yeteneği en yüksek olan öğrenci, yeteneği en düşük olan öğrenci, hangi öğrenci hangi maddeyi çözme yeteneğine sahiptir ya da hangi madde hangi öğrencinin yeteneğine uygundur, belirlenebilir. Bu çalışma sonucu elde edilen "madde haritası" aşağıda verilmiştir (Şekil 1). 


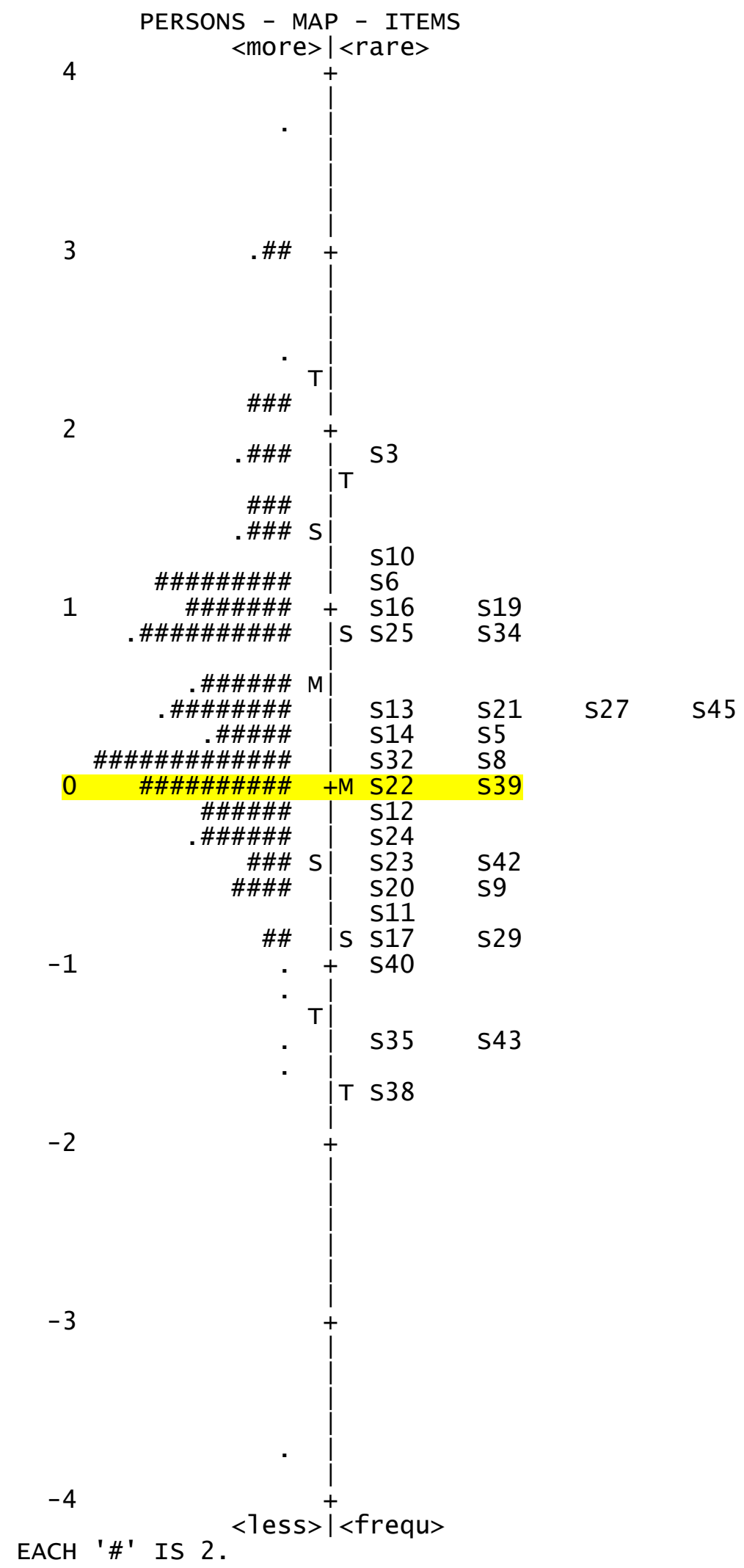

Şekil 1: Madde Haritası 
Madde haritasında, şeklin en sağında yer alan "4, 3, 2, 1, 0, -1, -2, -3 ve -4" değerleri "logit değerleri" dir ve yetenek düzeylerini ifade eder. Haritada logit değerlerinin yanında simgelerle gösterilenler ise bireyleri temsil eder ve "\#" simgesi iki bireyi "." (nokta) ise bir bireyi ifade eder. Şeklin en solunda yer alanlar ise ("S3" gibi) test maddelerini gösterir. Madde haritasında, maddeler güçlügüne, bireyler ise yeteneklerine göre sıralanmıştır. Verilen madde haritasında maddeler yukarıdan aşağıya en zor olandan en kolay olana doğru sıralanmıştır. Buna göre en zor soru "soru 3", en kolay soru ise "soru 38" dir.

Bireyler de sorulara paralel yetenek düzeyi yüksek olandan düşük olana doğru sıralanmıştır. Buna göre Biyoteknoloji ve Gen Mühendisliği konusu için Rasch modeli tarafından yetenek düzeyinin en yüksek olduğu tahmin edilen 1 birey vardır. Yani logit değerlerine göre 4' e en yakın konumda 1 kişi yer almaktadır. En altta "-4" düzeyinde de 1 birey yer almaktadır. Bu birey için de Biyoteknoloji ve Gen Mühendisliği konusu için Rasch modeli tarafindan yetenek düzeyinin en düşük olduğu tahmin edilen birey diyebiliriz.

Madde haritasında bireylerin bulunduğu logit değerinin altındaki sorular o bireyler için oldukça kolay, bulunduğu logit değerinin üstündeki sorular ise o bireyler için oldukça zor sorulardır. Dolayısıyla rasch analizine göre bir bireyin logit değerinin üstünde yer alan sorulara yanlış, altında yer alan sorulara ise doğru cevap vermesi beklenir. Dolayısıyla yukarıdaki harita incelendiğinde +4 ' e en yakın olan (en yüksek yetenek düzeyindeki) kişinin testteki bütün soruları çözebilecek yeteneğe sahip olduğunu söyleyebiliriz. Tam tersi -4' e en yakın olan (en düşük yetenek düzeyindeki) kişinin ise testteki soruların hiçbirini bilerek çözemeyeceğini söyleyebiliriz.

Buna göre madde haritası incelendiğinde hazırlanan ölçeğin çok zor olmadığı bulgusuna ulaşılabilir. Çünkü madde haritasına göre en zor soru "soru 3" tür ve soru 3 logit değerinin üzerinde yaklaşık 13 öğrenci yer almaktadır.

Madde haritasında aynı hizada yani aynı logit değerinde yer alan sorular aynı güçlüktedir. Eğer bu sorular aynı bilgiyi sorguluyorsa sorulardan birinin çıkarılması düşünülebilir. Bu ölçeğe ait madde haritası incelendiğinde "S16 ve S19", "S13, S21, S27, S45" aynı logit değerinde yer alan sorulardır. Ancak bu sorular aynı kavramı ölçmediği için, kapsam geçerliğini düşürmemek adına ölçekten çıkarılmamıştır.

\section{Sonuç ve Tartışma}

OBBT toplam 4 aşamada geliştirilmiştir. Dördüncü aşamada ölçeğin örnekleme uygunluğu, ölçekten elde edilen puanların güvenirliği ve geçerliği Rasch analizi ile kontrol edilmiştir. Bunun sonucunda geliştirilen; ölçek tek boyutludur, ölçeğin yapı geçerliliği uygundur. Bu da ölçekteki tüm maddelerin aynı şeyi ölçtüğünü yani geliştirilen ölçeğin kapsam ve yap1 geçerliğinin uygun olduğunu gösterir. Ölçekten elde edilen puanların güvenirliği .73' dür. Bilindiği gibi başarı testlerinde .50 üzeri bir ölçeğin güvenirliği için yeterlidir (Muijs, 2011). Ölçeğin madde ayırtedicilik indeksi 1.67' dir. Madde ayırtedicilik indeksinin 1 ve üzerinde olması ölçeği oluşturan maddelerin bilen ile bilmeyeni ayırt edebilecek güçte olduğunu gösterir. Ölçekte yanlı madde yoktur. DIF analizine göre ölçekte cinsiyete ya da sınıfa bağlı olarak avantaj oluşturan soru bulunmamaktadır. Bu tarz soruların bulunması ölçeğin güvenirliğini düşürecektir. Ölçek normal zorlukta bir ölçektir. Madde haritasına göre değerlendirildiğinde 
ölçekte çok zor ve çok kolay olarak belirlenen 1' er tane soru vardır. Bu 2 soruya rağmen ölçek orta zorlukta bir ölçek olarak kabul edilmiştir. Ölçme aracının uzmanlar tarafından kullanışlı olduğuna karar verilmiştir. Kapsam geçerliği uygundur.

Geliştirilen ve Rasch analizi ile psikometrik özellikleri test edilen OBBT'nin bir başarı testi olarak ortaöğretim öğrencilerine uygulanabilecek yapıda olduğu belirlenmiştir. $\mathrm{Bu}$ çalışmada oluşturulan ölçek Türkiye'de Biyoteknoloji ve Gen Mühendisliği konusu ile ilgili yapılan çalışmalarda kullanılan bazı ölçekler ile farklarını ortaya koymak amacıyla karşılaştırılmıştır. Karşılaştırma ölçeğin uygulandığ1 örneklemine, ölçek içeriğine, ölçeğin çeşidine ve ölçeğin analiz yöntemine bakılarak yapılmıştır.

$\mathrm{Bu}$ çalışmada geliştirilen ölçeğin örneklemi ortaöğretim öğrencileridir, örneklemi ortaöğretim öğrencileri olan 3 çalışmaya rastlanılmıştır. Özel ve diğerleri (2009) tarafından yapılan çalışmada kullanılan ölçeğin kapsamı daha dardır ve ortaöğretim kazanımları dikkate alınmamıştır. Diğer 2 çalışmada (Öz Aydın ve Sıcaker, 2015; Sıcaker, Çetin ve Öz Aydın, 2013) ise kavramlar anketi yer almaktadır, bilgi sorusu yoktur. Bu iki çalışmada da verilerin analizinde Klasik Test Kuramı temelli analizler kullanılmıştır. İncelenen diğer çalışmalarda ise örneklem İlköğretim öğrencilerinden (Bilen ve Özel, 2012; Demir ve Düzleyen, 2012), lisans öğrencilerinden (Darçın, 2007; Demir ve Düzleyen, 2012; Ergin ve diğerleri, 2008; Gürkan ve Kahraman, 2018; Keskin, 2003; Keskin ve diğerleri, 2010; Koçak ve diğerleri, 2010; Öcal, 2012; Öz Aydın ve diğerleri, 2016; Özdemir ve diğerleri, 2010; Sürmeli, 2008; Sürmeli ve Şahin, 2009; Tanır, 2005; Yılmaz ve Öğretmen, 2014; Yüce ve Yalçın, 2012) ve lisans mezunu kamu çalışanlarından (Bayoğlu ve Özgen, 2010; Demir ve Pala, 2007; Kaya, 2015; Özgen ve diğerleri, 2007) oluşmaktadır.

Bu çalışmada kullanılan ölçek bilgi ölçeğidir. Bilgi ölçeği kullanılan 18 çalışmaya rastlanmıştır bunlardan 6 tanesinde (Demir ve Pala, 2007; Demir ve Düzleyen, 2012; Gürkan ve Kahraman, 2018; Özgen ve diğerleri, 2007; Yılmaz ve Öğretmen, 2014; Yüce ve Yalçın, 2012) sadece bilgi ölçeği, diğer çalışmalarda (Bilen ve Özel, 2012; Darçın, 2007; Demir ve Düzleyen, 2012; Ergin ve diğerleri, 2008; Keskin, 2003; Keskin ve diğerleri, 2010; Koçak ve diğerleri, 2010; Özdemir ve diğerleri, 2010; Özel ve diğerleri, 2009; Sürmeli, 2008; Tanır, 2005; Yüce ve Yalçın, 2012) kullanılan ölçekler ise bilginin yanında tutum-risk algısı-fayda algısı da ölçen ölçeklerdir. Bilgi ölçeği kullanılan bu çalışmaların uygulandığı örneklemler incelendiğinde; 2 tanesinin ilköğretim öğrencilerinden (Bilen ve Özel, 2012; Demir ve Düzleyen, 2012), 13 tanesi lisans öğrencilerinden (Ergin ve diğerleri, 2008; Gürkan, 2013; Gürkan ve Kahraman, 2018; Kaya, 2015; Keskin ve diğerleri, 2010; Koçak ve diğerleri, 2010; Özdemir ve diğerleri, 2010; Özel ve diğerleri, 2009; Sürmeli, 2008; Sürmeli ve Şahin, 2009; Y1lmaz ve Öğretmen, 2014; Yüce ve Yalçın, 2012), 2 tanesinin lisans mezunu kamu çalışanlarından (Demir ve Pala, 2007; Özgen ve diğerleri, 2007) oluştuğu görülmektedir.

Ölçek içeriği olarak incelendiğinde ölçeğimiz ortaöğretim Biyoteknoloji ve Gen Mühendisliği konu ve kazanımlarına göre hazırlanmış, geniş kapsamlıdır. İncelenen çalışmalar arasında ortaöğretim konu ve kazanımlarını baz alan ve ortaöğretim öğrencilerine uygulanan ölçekler vardır (Öz Aydın ve diğerleri, 2016; Sıcaker, Çetin ve Öz Aydın, 2013) ancak bu ölçekler öğrencilerin sadece konuya ilişkin bilgilerini ölçmeye yönelik değildir.

$\mathrm{Bu}$ çalışmada geliştirilen ölçek aracılığı ile elde edilen veriler, ölçek geliştirme çalışmalarında büyük avantaj sağladığg düşünülen Rasch analizi ile analiz edilmiştir. İncelenen 
diğer çalışmaların bir tanesinin (Demir ve Pala, 2007) veri analizinde SAS V8.2 paket programı, diğerlerinde (Bayoğlu ve Özgen, 2010; Bilen ve Özel, 2012; Darçın, 2007; Demir ve Düzleyen, 2012; Ergin ve diğerleri, 2008; Gürkan, 2013; Gürkan ve Kahraman, 2018; Kaya, 2015; Keskin, 2003; Keskin ve diğerleri, 2010; Koçak ve diğerleri, 2010; Öcal, 2012; Öz Aydın ve diğerleri, 2016; Özdemir ve diğerleri, 2010; Özel ve diğerleri, 2009; Özgen ve diğerleri, 2007; Sicaker, Çetin ve Öz Aydın, 2013; Sıcaker ve Öz Aydın, 2015; Sürmeli, 2008; Sürmeli ve Şahin, 2009; Tanır, 2005; Yılmaz ve Öğretmen, 2014; Yüce ve Yalçın, 2012) ise SPSS (t-Testi, Anova, Manova, Faktör Analizi, Yüzde-Frekans, Varyans Analizi, Korelasyon) analiz yöntemleri kullanılmıştır.

Sonuç olarak geliştirilen OBBT’nin karşılaştırılan diğer 22 çalışmadan farkları; Ortaöğretim konu ve kazanımları dikkate alınarak hazırlanmış bilgi testi olması, biyoteknolojinin bir kısmına yoğunlaşmayıp genel konularını kapsıyor olması, hem de basit düzeyde bilgi sorularından oluşuyor olması, ortaöğretimin farklı alanlarından mezun her öğrenciye uygulanabilecek düzeyde olması, ölçeğin geliştirilme aşamasında Biyoteknoloji Kavram ve Bilgi Anketi ile Ortaöğretim öğrencilerinden veri toplanarak soru havuzu oluşturulması, verilerin analizinde birçok açıdan daha avantajlı olduğu düşünülen Rasch analizi kullanılmış olmasıdır. Bu yönleri ile OBBT' nin ortaöğretim için uygun bir ölçek olduğu ancak içeriği ortaöğretim program konularını kapsadığından bu yönünün ölçeğin bir sınırlığı olarak ifade edilebilir. 


\section{Kaynakça}

Anıl, D. (2008). Madde parametrelerinin klasik ve örtük özellikler test teorilerine göre kestirilmesi. Hacettepe Üniversitesi Ĕ̈itim Fakültesi Dergisi, 34, 1-11.

Anıl, D. (2002). Deneme uygulamasının yapılamadıgı durumlarda madde ve test parametrelerinin klasik ve örtük özellikler test teorilerine göre kestirilmesi. Doktora Tezi, Hacettepe Üniversitesi Sosyal Bilimler Enstitüsü, Ankara.

Atılgan, H. (2004). Genellenebilirlik kuramı ve çok değişkenlik kaynaklı rasch modelinin karşılaştırılmasına ilişkin bir araştırma. Doktora Tezi, Hacettepe Üniversitesi, Sosyal Bilimler Enstitüsü, Ankara.

Bahar, M., Nartgün, Z., Durmuş, S. ve Bıçak, B. (2010). Ölçme ve değerlendirme teknikleri, öğretmen el kitabı (4. baskl). Ankara: Pegem Akademi.

Baştürk, R. (2010). Bilimsel araştırma ödevlerinin çok yüzeyli rasch ölçme modeli ile değerlendirilmesi. Ĕgitimde ve Psikolojide Ölçme ve Değerlendirme Dergisi, 1(1), 51-57.

Bayoğlu, A. S. ve Özgen, Ö. (2010). Tüketicilerin tarımsal ve tıbbi biyoteknolojiye yönelik tutumları ile fayda ve risk algılarının incelenmesi. Uluslararası Sosyal Araştırmalar Dergisi (The Journal of International Social Research), 3(10), 90-103.

Bayraç, T. A., Kalemtaş, G., Baloğlu, M. C., Kavas, M. ve Önde, S. (2007). Genetiği değiştirilmiş organizmalar. ODTÜ Bilim ve Toplum Kitapları Dizisi. Ankara: ODTÜ Yayıncılık.

Berberoğlu, G. (1988). Seçme amacıyla kullanılan testlerde Rasch modelinin katkıları. Doktora Tezi, Hacettepe Üniversitesi, Sosyal Bilimler Enstitüsü, Ankara.

Bilen, K. ve Özel, M. (2012). Üstün yetenekli öğrencilerin biyoteknolojiye yönelik bilgileri ve tutumları. Necatibey Eğitim Fakültesi Elektronik Fen ve Matematik Ĕgitimi Dergisi, 6(2), 135152.

Bogner, A. \& Torgersen, H. (2014). Different ways of problematising biotechnology-and what it means for technology governance. Public Understanding of Science, 24(5), 516-532.

Boone, W. J. \& Scantlebury, K. (2005). The role of Rasch analysis when conducting science education research utilizing multiple-choice tests. Published online 15 November 2005 in Wiley Inter Science (www.interscience.wiley.com), 253-269. doi: 10.1002/sce.20106.

Boone, W. J., Staver, J. R., \& Yale, M. S. (2013). Rasch analysis in the human sciences. Springer Science $\&$ Business Media.

Bruschi, F., Dundar, M., Gahan, P. B., Gartland, K., Szente, M., Viola-Magni, M. P., \& Akbarova, $\quad$ Y. (2011). Biotechnology worldwide and the 'European biotechnology Thematic Network'association (EBTNA). Current Opinion In Biotechnology, 22(1), 7-14.

Büyüköztürk, Ş., Çakmak, E. K., Akgün, Ö. E., Karadeniz, Ş. ve Demirel, F. (2010). Bilimsel araştırma yöntemleri (6. Baskl). Ankara: Pegem Akademi.

Chabalengula, V. M., Mumba F. \& Chitiyo, J. (2011). American elementary education pre-service teachers' attitudes towards biotechnology processes. International Journal of Environmental \& Science Education, 6 (4), 341-357.

Chang, W. C. \& Chan, C. (1995). Rasch analysis for outcomes measures: some methodological considerations. Archives of physical medicine and rehabilitation, 76(10), 934-939. 
Çelik, O. ve Erişen, S. (2010). Ortaöğretim düzeyinde biyoloji dersi kapsamında uygulanan biyoteknoloji programının değerlendirilmesi. Gazi Üniversitesi Endüstriyel Sanatlar Eğitim Fakültesi Dergisi, 26, 25-39.

Çelik, V. ve Turgut Balık, D. (2007). Genetiği değiştirilmiş organizmalar (GDO). Erciyes Üniversitesi Fen Bilimleri Enstitüsü Dergisi, 23(1-2), 13-23.

Çepni, Z. (2011). Değişen madde fonksiyonlarinin sibtest, mantel haenzsel, lojistik regresyon ve madde tepki kuramı yöntemleriyle incelenmesi. Doktora Tezi, Hacettepe Üniversitesi, Sosyal Bilimler Enstitüsü, Ankara.

Çıkrıkçı Demirtaşlı, N. (1995). Test geliştirmede yeni yaklaşımlar: örtük özellikler kuramı-temel Özellikleri varsayımları, modeller ve sınırlılıkları. Ankara Üniversitesi Eğitim Bilimleri Fakültesi Dergisi, 28(2), 161-173. doi: 10.1501/Egifak_0000000298

Çoban, A. (2004). Biyoteknoloji, habermas ve kendimiz olmak. Mülkiye, (242), 237-253.

Darçın, E. S. (2007). Fen-teknoloji ve Biyoloji öğretmen adayları için Biyoteknoloji eğitiminin deneysel planlanması. Doktora Tezi, Gazi Üniversitesi, Eğitim Bilimleri Enstitüsü, Ankara.

Demir, B. ve Düzleyen, E. (2012). İlköğretim 8. sinı öğrencilerinin GDO bilgi düzeylerinin incelenmesi. X. Ulusal Fen Bilimleri ve Matematik Eğitimi Kongresi Niğde Üniversitesi, Eğitim Fakültesi, Niğde.

Demir, A. ve Pala, A. (2007). Genetiği değiş̧tirilmiş organizmalara toplumun bakış açısı. Hayvansal Üretim 48(1), 33-43.

Doğru, M. S. (2010). İlköğretim 8. Sinıf öğrencilerinin biyoteknoloji ile ilgili yaklaşımları ve bilgi seviyelerinin ölçülmesi. Yüksek Lisans Tezi, Kastamonu Üniversitesi, Fen Bilimleri Enstitüsü, Kastamonu.

Dundar, M. \& Akbarova, Y., (2011). Current state of Biotechnology in Turkey. Current Opinion in Biotechnology 22, 3-6.

Edmondston, J. E., Dawson, V. \& Schibeci, R. (2010). Undergraduate biotechnology students' views of science communication. International Journal of Science Education, 32(18), 2451-2474.

Elhan, A. H. ve Atakurt, Y. (2005). Ölçeklerin değerlendirilmesinde niçin Rasch analizi kullanılmalı. Ankara Üniversitesi Tip Fakültesi Mecmuası, 58, 47-50.

Elhan, A. H. (2002). Rasch analizinin incelenmesi ve fiziksel tip ve rehabilitasyon alaninda bir uygulaması. Doktora Tezi, Ankara Üniversitesi, Sağlık Bilimleri Enstitüsü, Ankara.

Erbaş, H. (2008). Türkiye'de Biyoteknoloji ve toplumsal kesimler. Profesyoneller, kentsel tüketiciler ve köylüler. Ankara Üniversitesi Biyoteknoloji Enstitüsü Yayınları, Ankara Üniversitesi Basımevi, Ankara.

Ergin, I., Gürsoy, Ş. T., Öcek, Z. A. ve Çiçeklioğlu, M. (2008). Sağllk meslek yüksekokulu öğrencilerinin genetiği değiştirilmiş organizmalara dair bilgi, tutum ve davranışları. TAF Preventive Medicine Bulletin, 7, 503-508.

Erkuş, A. (2012). Psikolojide ölçme ve ölçek geliştirme-l: temel kavramlar ve işlemler. Ankara: Pegem Akademi Yayıncılık.

Fonseca, M. J., Costa, P., Lencastre, L., \& Tavares, F. (2012). Disclosing biology teachers' beliefs about biotechnology and biotechnology education. Teaching and Teacher Education, 28(3), 368-381. 
Gelbal, S. (1994a). p Madde güçlük indeksi ile Rasch modelinin b parametresi ve bunlara dayall yetenek ölçüleri üzerine bir karşılaştırma. Doktora Tezi, Hacettepe Üniversitesi, Sosyal Bilimler Enstitüsü, Ankara.

Gelbal, S. (1994b). p madde güçlük indeksi ile Rasch. modelinin b parametresi ve bunlara dayalı yetenek ölçüleri üzerine bir karşılaştırma. Hacettepe Üniversitesi Eğitim Fakültesi Dergisi, (10), 85-94.

Güler, N. (2008). Klasik Test Kuramı Genellenebilirlik Kuramı ve Rasch Modeli üzerine bir araştırma. Doktora Tezi, Hacettepe Üniversitesi, Sosyal Bilimler Enstitüsü, Ankara.

Gültekin, S. (2011). Çoktan seçmeli, açık uçlu ve karma testlerin psikometrik özelliklerinin Madde Tepki Kuramına dayalı olarak değerlendirilmesi. Doktora Tezi, Ankara Üniversitesi, Eğitim Bilimleri Fakültesi, Ankara.

Gürkan, G. (2013). Fen bilgisi öğretmen adaylarl ve ögretmenlerinin biyoteknoloji ve genetik mühendisliği bilgi düzeylerinin çeşitli değişkenler açısından karşılaştırılması. Yüksek Lisans Tezi, İnönü Üniversitesi, Eğitim Bilimleri Enstitüsü, Malatya.

Gürkan, G. ve Kahraman, S. (2018). Fen bilgisi öğretmen adaylarının biyoteknoloji ve genetik mühendisliği bilgi düzeyleri. Karaelmas Ĕ̆itim Bilimleri Dergisi, 6(1), 25-39.

Gök, B. (2012). Denk olmayan gruplarda ortak madde deseni kullanılarak Madde Tepki Kuramına dayalı eşitleme yöntemlerinin karşılaştırılması. Doktora Tezi, Hacettepe Üniversitesi, Sosyal Bilimler Enstitüsü, Ankara.

Hambleton, R. K., \& Swaminathan, H. (1985). Item response theory: Principles and applications. Springer Science \& Business Media, New York.

Harlen W. (2001). The assessment of scientific literacy in the OECD/PISA Project. Studies in Science Education, 36(1), 79-104.

Harms, U. (2002). Biotechnology education in schools. Electronic Journal of Biotechnology ISSN:07173458, 5(3), 205-211.

Ho, M. W. (2001). Genetik Mühendisliği: Rüya mı kabus mu? (Çev: Emral Çakmak) İstanbul: Türkiye İş Bankası Kültür Yayınları.

Kaptan, F.(1994). Rasch modeli madde parametrelerini kullanarak en yüksek olabilirlik yöntemiyle yeteneğin kestirilmesi. Hacettepe Üniversitesi Eğitim Fakültesi Dergisi, 10, 95-97.

Kaskatı, O. T. (2011). Rasch modelleri kullanarak romatoid artirit hastaları özürlülük değerlendirimi için bilgisayar uyarlamalı test yönteminin geliştirilmesi. Doktora Tezi, Ankara Üniversitesi Sağlık Bilimleri Entitüsü, Ankara.

Kaya, H. (2015). Fen bilgisi öğretmenlerinin gözüyle Biyoteknoloji öğretimi. Yüksek Lisans Tezi, Çukurova Üniversitesi, Sosyal Bilimler Enstitüsü, Adana.

Kefi, S. (2003). Tarımsal Biyoteknoloji ve Biyogüvenlik. Tarım Ve Mühendislik TMMOB Ziraat Mühendisleri Odası Yayın Organı, 66-67, 69-79.

Kelecioğlu, H. (1994). Öğrenci seçme sınavı puanlarının eşitlenmesi üzerine bir çalışma. Doktora Tezi, Hacettepe Üniversitesi, Sosyal Bilimler Enstitüsü, Ankara.

Keskin, Y., Lüleci, N. E., Özyaral, O., Altıntaş, Ö., Sağlık, A., Lisar, H. ve diğerleri (2010). Maltepe Üniversitesi tıp fakültesi öğrencilerinin genetiği değiştirilmiş organizmalar hakkında bilgi tutum ve davranışları. Maltepe Tıp Dergisi, 2 (1), 14-23. 
Keskin, N. (2003). Fen bilgisi ĕgitimi 3. sınıf ögrencilerinin gen klonlama konusunu öğrenmelerine poster sunumu etkinliğinin etkisi. Yüksek Lisans Tezi, Gazi Üniversitesi, Eğitim Bilimleri Enstitüsü, Ankara.

Kilmen, S. (2010). Madde Tepki Kuramı"na dayalı test eşitleme yöntemlerinden kestirilen eşitleme hatalarının örneklem büyüklüğ̈̈ ve yetenek dă̆llımına göre karşılaştırılması. Doktora Tezi, Ankara Üniversitesi, Eğitim Bilimleri Enstitüsü, Ankara.

Kirkpatrick, G., Orvis, K., ve Pittendrigh, B. (2002). A teaching model for biotechnology and genomics education. Journal of Biological Education, 37(1), 31-35.

Köse, İ. A. (2012). Çok Boyutlu Madde Tepki Kuramı. Eğitimde ve Psikolojide Ölçme ve Değerlendirme Dergisi, 3(1), 221-229.

Koçak, N., Türker, T., Kılıç, S., ve Hasde, M. (2010). Tıp fakültesi öğrencilerinin genetiği değiştirilmiş organizmalar hakkındaki bilgi, tutum ve davranışlarının belirlenmesi. Gülhane-Tıp Dergisi, 52(3), 198-204.

Kolarova, A. T. (2011). Modern Biotechnology from the point of view of 15-19-year-old high school students. Biotechnology \& Biotechnological Equipment, 25(3), 2538-2546.

Koparan, T. ve Güven, B. (2013). Proje tabanlı öğrenme yaklaşımının ilköğretim öğrencilerinin örneklem kavramına yönelik istatistiksel okuryazarlık seviyesine etkisi. Ĕ̆itim ve Öğretim Araştırmaları Dergisi, 2 (1), 20.

Kulaç, İ., Ağırdil, Y. ve Yakın, M. (2006). Sofralarımızdaki tatlı dert, genetiği değiştirilmiş organizmalar ve halk sağlığına etkileri. Türk Biyokimya Dergisi, 31(3), 151-155.

Küçükdeveci, A. (2011). Osteoartritte işlevsel değerlendirme ölçütleri. Türk Geriatri Dergisi Özel Sayı (1), 37-44.

Kwon, H. (2009). Key factors affecting the implementation of biotechnology instruction in secondary school level technology education classrooms. Doctoral dissertation, Virginia Polytechnic Institute, Virginia.

Lamanauskas, V. \& Makarskaitė-Petkevičienè, R. (2008) Lithuanian University students' knowledge of biotechnology and their attitudes to the taught subject. Eurasia Journal of Mathematics, Science \& Technology Education, 4 (3), 269-277.

Linacre, M. (2006). Winsteps, Version 3.65. Chicago, IL: MESA Press.

Miller, M. B. (1994). Practical DNA technology in school. Journal of Biological Education, 28(3), 203211.

Mehta, M. D., \& Gair, J. J. (2001). Social, political, legal and ethical areas of inquiry in biotechnology and genetic engineering. Technology in Society, 23(2), 241-264.

Muijs, D. (2011). Doing Quantitative Research in Education With SPSS. SAGE Publications Ltd. Ebook ISBN:9781446210147

Öcal, E. (2012). İlköğretim Fen bilgisi öğretmenlerinin Biyoteknoloji (Genetik Mühendisliği) farkındalık düzeyleri. Yüksek Lisans Tezi, İnönü Üniversitesi Eğitim Bilimleri Enstitüsü, Malatya.

Öktem, H. A. (2007). Yeni nesil transgenikler. 6. Ankara Biyoteknoloji Günleri: Biyoteknoloji, Biyogüvenlik ve Sosyo-Ekonomik Yaklaşımlar, Ankara Üniversitesi Biyoteknoloji Enstitüsü, Ankara. 
Öz Aydın, S., Sicaker, A, Taşkın, N. T. ve Şahin, S. (2016). Biyoteknoloji algısı ölçeği (BAÖ): Türkçe'ye uyarlama, geçerlik ve güvenirlik çalışması. I. Ulusal Biyoloji Eğitimi Kongresi. Gazi Üniversitesi Gazi Eğitim Fakültesi, Ankara.

Özdemir, O., Güneş, M. H. ve Demir, S. (2010). Üniversite öğrencilerinin genetiği değiştirilmiş organizmalara (GDO’lara) yönelik bilgi düzeyleri-tutumları ve sürdürülebilir tüketim eğitimi açısından değerlendirilmesi. Ondokuz Mayıs Üniversitesi Eğitim Fakültesi Dergisi, 29 (1), 5368 .

Özel, M., Erdoğan, M., Uşak, M. ve Prokop, P. (2009). Lise öğrencilerinin biyoteknoloji uygulamalarına yönelik bilgileri ve tutumları. Science Education, 2(10), 61-69.

Özgen, Ö., Emiroğlu, H., Yıldız, M., Taş, A.S. ve Purutçuoğlu, E. (2007). Tüketiciler ve Modern Biyoteknoloji: Model Yaklaşımlar. Ankara Üniversitesi Biyoteknoloji Enstitüsü Yayınları, Ankara Üniversitesi Basımevi, Ankara.

Özkan Özer, Y. (2012). Öğrenci Başarılarının Belirlenmesi Sinavından (ÖBBS) Klasik Test Kuramı, Tek Boyutlu Ve Çok Boyutlu Madde Tepki Kuramı Modelleri İle Kestirilen Başarı Puanlarının Karşılaştırllması. Doktora Tezi, Ankara Üniversitesi, Eğitim Bilimleri Enstitüsü, Ankara.

Özkaya Seçil, S. (2009). The Investigation Of Cognitive Processes In Mathematics Learning With Item Response Theory. Ph.D.A, Thesis Submitted To The Graduate School Of Natural And Applied Sciences Of Middle East Technical University, Ankara.

Öztuna, D. (2008). Kas-iskelet sistemi sorunlarının özürlülük değerlendiriminde bilgisayar uyarlamalı test yönteminin uygulanması. Doktora Tezi, Ankara Üniversitesi, Sağlık Bilimleri Enstitüsü, Ankara.

Pekşen, Z. (2009). Bilim-Teknoloji eğitiminde yenilikçi yaklaşımlar ve biyoteknoloji eğitimi. Bilim ve Teknik Dergisi, 505, 60-63.

Semerci, Ç. (2011a). Mikroöğretim uygulamalarının Çok Yüzeyli Rasch Ölçme Modeli ile analizi. Eğitim ve Bilim, 36(161), 14-25.

Semerci, Ç. (2011b). Doktora yeterlikler çerçevesinde öğretim üyesi, akran ve öz değerlendirmelerin Rasch ölçme modeliyle analizil. Eğitimde ve Psikolojide Ölçme ve Değerlendirme Dergisi, 2(2), 164-17.

Sicaker, A., Çetin, G., ve Öz Aydın, S. (2013). 11. ve 12. sinlf öğrencilerinin biyoteknoloji konusu ile ilgili düşünceleri. In International Conference on Primary Education. North Cyprus.

Simonneaux, L. (2002). Analysis of classroom debating strategies in the field of biotechnology. Journal of Biological Education, 37(1), 9-12. doi: 10.1080/00219266.2002.9655839

Sıcaker, A. ve Öz Aydın, S. (2015). Ortaöğretim Biyoteknoloji ve gen mühendisliği kavramlarının öğrenciler tarafindan değerlendirilmesi. Ondokuz Mayls Üniversitesi Eğitim Fakültesi Dergisi, 34(2), 51-67.

Sürmeli, H. (2008). Üniversite ögrencilerinin Biyoteknoloji ve Genetik Mühendisliği çalışmaları ile ilgili tutum, bilgi ve biyoetik görüşlerinin değerlendirilmesi. Doktora Tezi, Marmara Üniversitesi, Eğitim Bilimleri Enstitüsü, İstanbul.

Sürmeli, H. ve Şahin, F. (2009). Üniversite öğrencilerinin Biyoteknoloji çalışmalarına yönelik bilgi ve görüşleri. Çukurova Üniversitesi Eğitim Fakültesi Dergisi, 37, 33-45.

Sünbül, Ö. (2011). Çeşitli boyutluluk özelliklerine sahip yapllarda, madde parametrelerinin değişmezliğinin Klasik Test Teorisi, Tek Boyutlu Madde Madde Tepki Kuramı ve Çok Boyutlu 
Madde Tepki Kuramı çerçevesinde incelenmesi. Doktora Tezi, Mersin Üniversitesi, Eğitim Bilimleri Enstitüsü, Mersin.

Tanır, S. (2005). Çukurova Üniversitesi birinci sınıffen grubu öğrencilerinin "Biyoteknoloji ve Genetik Mühendisliği" konusundaki bilgilerinin değerlendirilmesi. Yüksek Lisans Tezi, Gazi Üniversitesi, Eğitim Bilimleri Enstitüsü, Ankara.

T.C. Milli Eğitim Bakanlığı, (2013). Talim ve Terbiye Kurulu başkanlı̆̆ı Ortaöğretim Biyoloji dersi ögretim programı. http://ttkb.meb.gov.tr/www/ogretim programlari/icerik/72.

Tekin, H. (1991). Ĕgitimde ölçme ve değerlendirme. Ankara: Yargı Yayınevi.

Yılmaz, M. ve Öğretmen, T. (2014). Biyoloji öğretmen adaylarının gen teknolojisine ilişkin bilgi düzeyleri ve bilgi kaynaklarının incelenmesi. Pegem Ĕ̆itim ve Öğretim Dergisi, 4(4), 59-76.

Yu, C. H. (2013). A Simple Guide to the Item Response Theory (IRT) and Rasch Modeling [online]. http://www.creative-wisdom.com/computer/sas/IRT.pdf.

Yüce, Z. ve Yalçın, N. (2012). Fen bilgisi öğretmen adaylarının Biyoteknoloji konusundaki bilgi düzeyleri. X. Ulusal Fen Bilimleri ve Matematik Eğitimi Kongresi. Niğde Üniversitesi Eğitim Fakültesi, Niğde.

Wells, J. G. (1992). Establishment of a taxonometric structure for the study of biotechnology as a secondary school component of technology education. Unpublished doctoral dissertation, Virginia Polytechnic Institute and State University.

Wright, B.D. \& Linacre, J.M. (1994). Reasonable mean-square fit values. Transactions of the Rasch measurement SIG American educational research association. Rasch measurement Transaction, 8(3), 370-382.

Wright, B. D. \& Mok, M. C. M. (2004). An Overview of the Family of Rasch Measurement Models. Introduction To Rasch Measurement, 1-24.

Wright, B. D. \& Stone, M. H. (1979). Best Test Design. Chicago: Mesa Press.

Wuang, Y.P., Lin, Y. H. \& Su, C.Y. (2009). Rasch analysis of the Bruininks-Oseretsky Test of Motor Proficiency-Second Edition in intellectual disabilities. Research in Developmental Disabilities, 30, 1132-1144. 


\section{Extended Abstract}

\section{Introduction}

The science of biotechnology is essential for the future of societies. Biotechnological methods are offering various advantages, but at the same time they create high anxiety and unrest in many areas of people's daily lives (Bayraç, Kalemtaş, Baloğlu, Kavas, \& Önde, 2007; Bogner \&Torgersen, 2014; Çelik \& Balık, 2007; Çoban, 2004; Edmondston, Dawson, \& Schibeci, 2010; Ho, 2001; Kefi, 2003; Kulaç, Ağırdil, \& Yakın, 2006; Öktem, 2007; Simonneaux, 2002; Sürmeli, 2008). Therefore, having the actual knowledge of previously applied and future practices, the ethical considerations and legal regulations on this subject may lead the modern technology in the desired direction (Mehta \& Gair, 2001) and may limit the concerns. Such biotechnology knowledge, on the other hand, should be associated with daily life rather than being merely conceptual to have an impact on the quality of an individual's life. (Kirkpatrick, Orvis, \& Pittendrigh, 2002; Wells, 1992). However, evaluating biotechnology knowledge requires useful instruments for researchers to determine if individuals have it accurately.

Besides, a literature review on this subject did not reveal a scale developed within the framework of the content and learning outcomes of The Turkish Secondary School Biology Curriculum. Based on the indicated requirements, the present research aimed to develop a scale to determine secondary school students' knowledge levels on biotechnology and genetic engineering topics. We followed all the necessary steps for scale development. Scale and item analysis was the last stage recommended for this very long and challenging process. In this stage, we calculated the reliability and validity of the scores obtained, the item degrees of difficulty for the study group and the item discrimination index using various statistical analysis methods (Erkuş, 2012). We used one of the suggested analysis methods, the Rasch Measurement Model, which is thought to have significant advantages for scale development research. In Rasch Measurement model, each item along the variable exhibits a probability of the respondent correctly answering each item, resulting parameters do not depend on the sample's mean location or its dispersion and biased items could be identified (Boone \& Scantlebury, 2005; Wright \& Mok, 2004). We thought this scale would provide a useful assessment for various dimensions of and make a significant contribution to biotechnology and genetic engineering education by filling a gap in the sense of determining the levels of knowledge, competencies, and abilities of secondary school students.

\section{Method}

The sample of the present study consisted of 11th and 12th-grade secondary school students from a province in the Marmara Region of Turkey. We started with constituting "The Biotechnology Knowledge and Concepts Scale (BKCS)" according to The Turkish Secondary School Biology Curriculum. We carefully examined the "Heredity, Genetic Engineering, and Biotechnology" Unit of the curriculum along with the 2012- 2013 school year 11th-grade Biology Textbook. BKCS aimed to collect students' ideas about various concepts such as Transgenic Organism, Microinjection Method, DNA Isolation, Recombinant DNA, Cloning, and Biosafety (see also Sicaker \& Öz Aydın, 2015). We used the findings of BKCS in addition to the learning outcomes of the topic to form the true-false type "The Secondary School Biotechnology Knowledge Test (SBKT)" in four steps. We used Rash Measurement Model to 
test the convenience of the sample, the validity, and reliability of the scores obtained from SBKT (The Secondary School Biotechnology Knowledge Test).

\section{Findings}

Data analysis with Rash Measurement model showed that SBKT is unidimensional (infit-outfit values are between .05 and 1.2). Also, SKBT produced valid and reliable scores (reliability index=.73), item discrimination index of the scale is 1.67 (which means the items sorts students who have mastered the material from students who have not), and there are no biased items in the scale. Besides, based on the field expert opinions, we decided that SKBT is convenient and has content validity.

\section{Results}

Findings of the study revealed that the structure of SKBT is suitable for secondary school students as an achievement test. Comparing and contrasting the sample, the content and the our analysis method of SKBT with other scales about Biotechnology and Genetic Engineering topic in Turkey also revealed that (Bayoğlu \& Özgen, 2010; Bilen \& Özel, 2012; Tanır, 2005; Özgen, Emiroğlu, Yıldız, Taş \& Purutçuoğlu, 2007; Darçıı, 2007; Demir \& Pala, 2007; Demir \& Düzleyen, 2012; Ergin, Gürsoy, Öcek \& Çiçeklioğlu, 2008; Gürkan, 2013; Gürkan \& Kahraman, 2018; Kaya, 2015; Keskin, 2003; Keskin et al., 2010; Koçak, Türker, Kılıç \& Hasde, 2010; Öcal, 2012; Özdemir, Güneş \& Demir, 2010; Özel, Erdoğan, Uşak \& Prokop, 2009; Öz Aydın, Sıcaker, Taşkın \& Şahin, 2016; Sıcaker, Çetin \& Öz Aydın, 2013; Sicaker \& Öz Aydın, 2015; Sürmeli, 2008; Sürmeli \& Şahin, 2009; Yılmaz \& Öğretmen, 2014; Yüce \& Yalçın, 2012);

- the measurement and Evaluation tools about Biotechnology in the literature is generally narrow-scoped (only questioning about one dimension such as GMO's and/or not including overall aims and outcomes of the curriculum),

- the items in those scales focused more on determining the attitudes, perceptions of risk and interest than knowledge about the topic,

- the sample generally consisted of pre-service students and public workers with Bachelor's Degrees, a few studies focused on secondary school students.

Consequently, SKBT's differences with previous studies in the literature are;

- being a knowledge test formed in accordance with secondary school content and learning outcomes,

- consisting of basic level knowledge questions,

- being convenient for all secondary school graduates from different secondary school backgrounds,

- collecting data from secondary school students with "The Biotechnology Knowledge and Concepts Scale" and constituting an item pool before developing the scale,

- using the Rasch Measurement Model's advantages to analyze the data. 
Within the above mentioned aspects, it can be stated that SKBT is convenient in various respects. However, since it only covers the secondary school contents, it creates a limitation for the scale.

\section{EK}

\section{OBBT SORULARI}

Madde Haritasına Göre Soruların

Zorluk Kolaylık Derecesi

1- "Transgenik Organizma" genetiği değiştirilmiş hayvanlar için, "GDO (Genetiği

S3 en zor soru

Değiştirilmiş Organizma)" ise genetiği değiştirilmiş bitkiler için kullanılan bir kavramdır.

\begin{tabular}{l|l}
\hline 11- GDO’lu besin hormonlu besin demektir. & S16 Zor olarak 4. sirada \\
\hline 12- İnsanlarda suni döllenme yöntemi kullanılmaz. & S17 Kolay olarak 4. Sirada \\
\hline 14- Gen aktarımı sadece bitkiden bitkiye yapılabilir. & S20 Kolay olarak 6. sirada \\
\hline 16- Bitkiden hayvana gen aktarımı yapılabilir. & S22 "0" logit değerinde orta zorlukta \\
\hline 30- Doğada türler arasında doğal olarak gen aktarımı olmaz. & S45 Zor olarak 6. sirada \\
\hline
\end{tabular}

